\title{
PENGARUH MODEL PEMBELAJARAN KOOPERATIF TIPE STAD \\ BERBANTUAN MEDIA ANIMASI TERHADAP HASIL BELAJAR \\ SISWA PADA MATERI POKOK SUHU DAN KALOR \\ DI KELAS X SMA SWASTA NUSANTARA \\ LUBUK PAKAM T.P 2015/2016
}

\author{
Dessy Yulia Sitepu dan Henok Siagian \\ (Jurusan Fisika FMIPA Universitas Negeri Medan) \\ dessitepu@yahoo.com
}

\begin{abstract}
This study aims to find out there is a difference in student learning outcomes as a result of thr influence by using cooperative learning model type STAD media aided animation is better than direct learning model in the subject matter of temperture and heat in class X SMA Swasta Nusantara Lubuk Pakam T.P.2015/2016. The study was quasi-experiment with design two group pretestpostest. To obtain the necessary data in this study used multiple-choice test with a number of 20 items that have been validated in accordance with the standards of good questions. The results of hypothesis testing using one t-test of the party obtained no significant difference due to the influence by using cooperative learning model type STAD media aided animation is better than direct learning model in the subject matter of temperture and heat in class X SMA Swasta Nusantara Lubuk Pakam T.P.2015/2016.
\end{abstract}

Keywords: cooperative learning model type STAD, direct learning model, media animation, learning outcomes.

\begin{abstract}
ABSTRAK
Penelitian ini bertujuan untuk mengetahui ada perbedaan hasil belajar siswa akibat pengaruh model pembelajaran kooperatif tipe STAD berbantuan media animasi terhadap hasil belajar siswa pada materi pokok Suhu dan Kalor di kelas X semester II SMA Swasta Nusantara Lubuk Pakam T.P 2015/2016. Jenis penelitian ini adalah penelitian quasi experiment dengan desain two group pretest-postest. Instrumen yang digunakan dalam penelitian ini yaitu tes pilihan berganda dengan jumlah 20 item yang telah divalidasi sesuai dengan standar soal yang baik. Hasil uji hipotesis menggunakan uji beda (uji- $t$ satu pihak) diperoleh ada perbedaan yang signifikan akibat pengaruh penerapan model kooperatif tipe STAD berbantuan media animasi terhadap hasil belajar siswa pada materi pokok Suhu dan Kalor di kelas X semester II SMA Swasta Nusantara Lubuk Pakam T.P 2015/2016.
\end{abstract}

Kata Kunci: model pembelajaran kooperatif tipe STAD, model pembelajaran langsung, media animasi, hasil belajar. 


\section{PENDAHULUAN}

\begin{tabular}{|c|c|}
\hline \multirow{3}{*}{\multicolumn{2}{|c|}{$\begin{array}{l}\text { Pendidikan } \\
\text { kegiatan merupakan } \\
\text { perkembangan potensi, kecakapan, } \\
\text { dan karakteristik pribadi peserta } \\
\text { didik. Kegiatan pendidikan diarahkan } \\
\text { kepada pencapaian tujuan } \\
\text { pendidikan. Tujuan pendidikan } \\
\text { minimal diarahkan keempat sasaran, } \\
\text { yaitu :pengembangan segi-segi }\end{array}$}} \\
\hline & \\
\hline & \\
\hline $\begin{array}{l}\text { kepribadian, } \\
\text { kemampuan } \\
\text { pengembangan }\end{array}$ & $\begin{array}{r}\text { pengembangan } \\
\text { masyarakat }\end{array}$ \\
\hline helanjutkan & $\begin{array}{ll}\text { studi, } & \mathrm{d} \\
\text { kecakapan } & \mathrm{d}\end{array}$ \\
\hline & \\
\hline
\end{tabular}

Pendidikan merupakan suatu kegiatan yang berintikan interaksi antara peserta didik dengan para pendidik serta berbagai sumber pendidikan. Interaksi antara pendidik dengan peserta didik dan sumbersumber pendidikan tersebut dapat berlangsung dalam situasi pergaulan (pendidikan), pengajaran, latihan, serta bimbingan. Interaksi juga sangat dibutuhkan dalam pendidikan fisika karena pendidikan fisika merupakan pendidikan yang mengembangkan cara berpikir yang kritis, sistematis, logis, kreatif, dan inovatif dalam membentuk manusia yang handal dan mampu berkompetensi secara global.

Fisika sebagai bagian dari

Ilmu Pengetahuan Alam (IPA) merupakan mata pelajaran yang menarik dan lebih banyak memerlukan pemahaman daripada penghafalan. Pengetahuan fisika yang dilakukan melalui kegiatan belajar akan menjadi landasan penguasaan ilmu pengetahuan dan teknologi (IPTEK), dan pendidikan dari tingkat bawah ketingkat berikutnya.

Fisika adalah ilmu yang mempelajari gejala alam yang tidak hidup atau materi dalam lingkup ruang dan waktu. Guru dalam memberikan pembelajaran fisika dituntut untuk dapat membuat siswa memahami akan gejala-gejala fisis yang diukur,memahami simbol serta besaran-besaran yang ada dalam fisika.

Berdasarkan observasi awal peneliti pada masa PPLT 2015 di SMA Swasta Yapim Simpang Kawat bahwa pendekatan pembelajaran yang diterapkan di kelas masih berpusat kepada guru sehingga siswa tidak turut aktif dalam proses pembelajaran. Proses pembelajaran yang digunakan adalah model pembelajaran langsung. Di samping itu, siswa juga jarang melakukan praktikum secara langsung di laboratorium karena kurangnya sarana dan prasarana yang ada di sekolah. Hal tersebut menyebabkan siswa yang bersangkutan sulit mengingat apa yang telah dipelajarinya dan mudah dilupakan. Selain itu juga disebabkan oleh faktor dimana siswa beranggapan bahwa pelajaran fisika itu sulit karena banyakan rumus-rumus yang membingungkan untuk diselesaikan dan guru juga tidak pernah bercerita bagaimana hubungan fisika dalam kehidupan sehari - hari sehingga siswa tidak menyukai pelajaran fisika.

Model kooperatif tipe STAD, yaitu suatu model pembelajaran yang dapat mengaktifkan siswa dalam proses belajar mengajar dalam bentuk kelompok. Karena selain permasalahan hasil belajar saja maka 
model ini juga akan diintegrasikan dengan pendidikan karakter. (Jurnal Tanjung: 2013).

Menurut Slavin (2005:143) Student Team Achievement Division (STAD merupakan salah satu metode pembelajaran kooperatif yang paling sederhana, dan merupakan model yang paling baik untuk permulaan bagi para guru yang baru menggunakan pendekatan kooperatif.

Menurut Slavin (2005:12), gagasan utama dari STAD adalah untuk memotivasi siswa supaya dapat saling mendukung dan membantu satu sama lain dalam menguasai kemampuan yang diajarkan oleh guru. Jika para siswa ingin agar timnya mendapatkan penghargaan tim, mereka harus membantu teman satu timnya untuk mempelajari materinya.

Penggunaan kooperatif tipe STAD dapat membuat siswa menjadi lebih aktif karena siswa dituntut untuk saling bekerja sama dengan teman yang lainnya. Selain itu, di dalam model kooperatif tipe STAD juga terdapat penghargaan sehingga siswa lebih antusias dalam belajar, mereka akan berlomba-lomba untuk menjadi kelompok yang terbaik.

Berdasarkan hal-hal tersebut, peneliti tertarik untuk melakukan penelitian dengan tujuan untuk melihat pengaruh model kooperatif tipe STAD berbantuan media animasi terhadap hasil belajar siswa (sikap, keterampilan dan pengetahuan) selama proses pembelajaran berlangsung.

\section{METODE PENELITIAN}

Penelitian dilaksanakan di SMA Swasta Nusantara Lubuk Pakam yang beralamat di Jl.Tengku
Raja Muda No.1 Kecamatan Lubuk Pakam dengan waktu pelaksanaan semester II T.P.2015/2016. Populasi dalam penelitian adalah seluruh siswa kelas $\mathrm{X}$ SMA Swasta Nusantara Lubuk Pakam yang terdiri dari 6 kelas paralel berjumlah 220 orang pada T.P. 2015/2016.

Sampel dalam penelitian terdiri dari dua kelas yaitu kelas kontrol dan kelas eksperimen yang diambil dengan teknik cruster random sampling. Satu kelas dijadikan sebagai kelas eksperimen yaitu kelas X-4 yang diajar dengan model pembelajaran kooperatif tipe STAD berbantuan media animasi dan satu kelas lagi dijadikan sebagai kelas kontrol yaitu kelas X-5 yang diajar dengan model pembelajaran langsung. Jenis penelitian ini adalah penelitian quasi eksperimen. Desain dalam penelitian ini menggunakan two group pretest - postest design seperti ditunjukkan pada Tabel 1 .

Tabel 1. Desain Penelitian (Two

Group Pretest - Postest Design)

\begin{tabular}{|l|l|l|l|}
\hline Kelas & Pretes & Perlakuan & Postes \\
\hline Eksperimen & $\mathrm{T}_{1}$ & $\mathrm{P}$ & $\mathrm{T}_{2}$ \\
\hline Kontrol & $\mathrm{T}_{1}$ & $\mathrm{Q}$ & $\mathrm{T}_{2}$ \\
\hline
\end{tabular}

(Arikunto,2012:85)

Keterangan :

$\mathrm{T} 1=$ Pemberian tes awal (pretes)

$\mathrm{T} 2=$ Pemberian tes akhir (postes)

$\mathrm{X}=$ Perlakuan dengan model pembelajaran kooperatif tipe STAD berbantuan media animasi.

$\mathrm{Y}=$ Menggunakan model pembelajaran langsung. 


\section{HASIL DAN PEMBAHASAN}

\section{a. Hasil Penelitian}

Awal penelitian kedua kelas diberikan tes uji kemampuan awal (pretes) yang bertujuan untuk mengetahui kemampuan awal siswa pada kedua kelas sama atau tidak. Berdasarkan data hasil penelitian pada lampiran diperoleh nilai ratarata pretes siswa pada kelas eksperimen sebelum diberi perlakuan dengan menggunakan model pembelajaran kooperatif tipe STAD berbantuan animasi sebesar 33,89 dengan standar deviasi 9,42 dan di kelas kontrol diperoleh nilai rata-rata pretest siswa sebesar 34,05 dengan standar deviasi 10,92.

Untuk melihat secara rinci hasil pretes kedua kelas dapat dilihat pada diagram batang berikut:

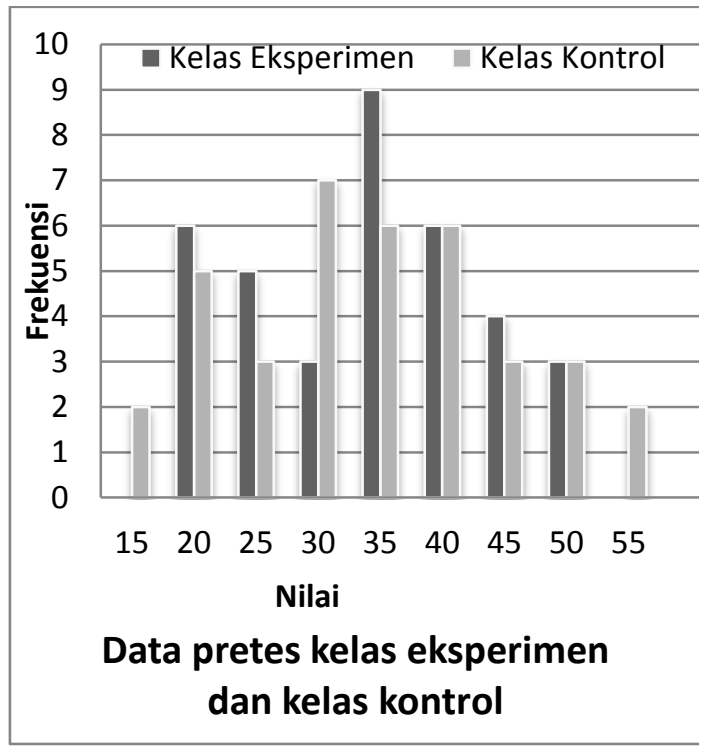

Gambar 1 . Hubungan Pretes Kelas Eksperimen dan Kontrol

Gambar 1 di atas menunjukkan nilai pretes pada kelas eksperimen dan kelas kontrol tidak jauh berbeda, artinya kedua kelas mempunyai kemampuan awal yang hampir sama dan perolehan nilai kedua kelas merata.

Sebelum dilakukan uji hipotesis terlebih dahulu dilakukan uji prasyarat data yaitu uji normalitas menggunakan uji Lilliefors. Hasil uji normalitas yang diperoleh adalah Kelas Eksperimen $L_{\text {hitung }}=0,1320$, $\mathrm{L}_{\text {tabel }}=0,1477$. Untuk kelas kontrol $\mathrm{L}_{\text {hitung }}=0,1038, \mathrm{~L}_{\text {tabel }}=0,1457$. Kesimpulannya kedua kelas berdistribusi normal.

Pengujian homogenitas dilakukan untuk mengetahui apakah kelas sampel berasal dari populasi yang homogen atau tidak, artinya apakah sampel yang dipakai dalam penelitian ini dapa tmewakili seluruh populasi yang ada.

Pengujian homogenitas data dilakukan dengan uji F. Hasil uji homogenitas data yang diperoleh adalah $F_{\text {hitung }}<\mathrm{F}_{\text {tabel }}=1,344<1,776$.

NilaiF $F_{\text {hitung }}<\mathrm{F}_{\text {tabel }}$ yang berarti bahwa sampel yang digunakan dalam penelitian ini dinyatakan homogen atau dapat mewakili seluruh populasi yang ada.

Setelah kedua kelas diberikan perlakuan yang berbeda, kedua kelas selanjutnya diberikan postes dengan soal yang sama seperti soal pretest yang bertujuan untuk mengetahui hasil belajar siswa. Hasil yang diperoleh adalah Berdasarkan data hasil penelitian pada lampiran diperoleh nilai rata-rata postes siswa pada kelas eksperimen setelah diberi perlakuan dengan menggunakan model pembelajaran kooperatif tipe STAD berbantuan media animasi sebesar 85,97 dengan standar deviasi 7,54 dan di kelas kontrol diperoleh nilai rata-rata postest siswa sebesar 78,11 dengan standar deviasi 7,67. 
Untuk melihat secara rinci hasil postes kedua kelas dapat dilihat pada diagram batang berikut:

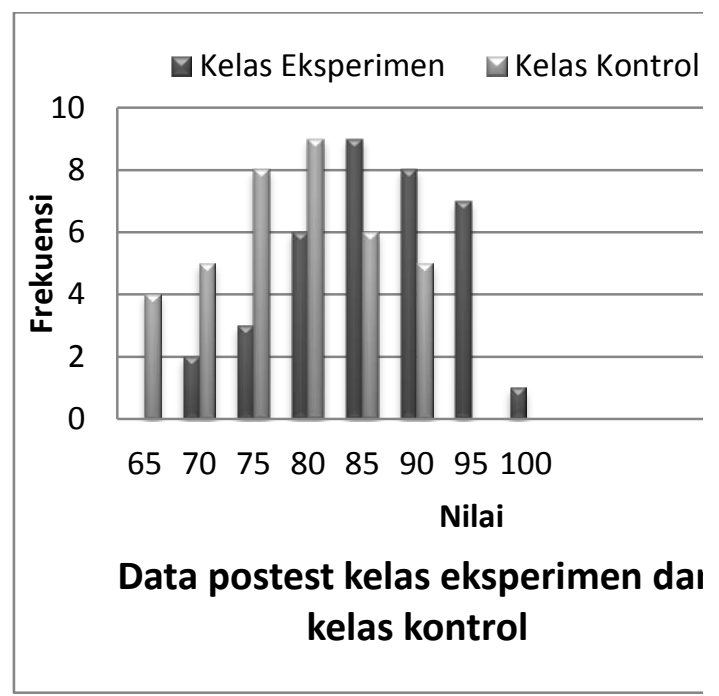

Gambar 2.Perbandingan Nilai Postes Kelas Eksperimen dan Kontrol

Gambar 2 menunjukkan bahwa pada kelas eksperimen, nilai yang dicapai oleh siswa lebih merata dibandingkan pada kelas kontrol. Hal ini menunjukkan bahwa penerapan model pembelajaran kooperatif tipe STAD berbantuan media animasi baik untuk dilakukan.

Berdasarkan hasil uji hipotesis diperoleh $t_{\text {hitung }}>t_{\text {tabel }}=$ $4,42>1,67$. Dalam hal ini dapat disimpulkan bahwa ada pengaruh yang signifikan akibat model pembelajaran Kooperatif Tipe STAD Berbantuan Media Animasi terhadap hasil belajar pada materi pokok Suhu dan Kalor di kelas X SMA Swasta Nusatara Lubuk Pakam T.P 2015/2016.

\section{b. Pembahasan}

Hasil menunjukkan hipotesis kemampuan awal pada kelas eksperimen dan kelas kontrol adalah sama, hal ini berarti kesadaran siswa untuk belajar di rumah sebelum mempelajari di sekolah masih sangat rendah. Akan tetapi setelah peneliti memberikan perlakuan kepada kedua kelas yaitu kelas eksperimen dengan model pembelajaran kooperatif tipe STAD berbantuan media animasi dan kelas kontrol dengan pembelajaran langsung, diperoleh peningkatan hasil belajar. Pada kelas eksperimen hasil belajar siswa mengalami peningkatan, yaitu dari nilai 33,89 menjadi 85,97 . Sama halnya dengan kelas eksperimen, kelas kontrol juga mengalami peningkatan hasil belajar setelah diberikan perlakuan dengan menggunakan pembelajaran langsung, namun peningkatan pada kelas kotrol tidak sama besarnya dengan kelas eksperimen, yaitu pada tes hasil belajar peningkatan dari hasil awal, yaitu 34,05 menjadi 78,11 .

Hasil kemampuan akhir siswa yang berujuk pada tabel 4.1 dan 4.2 juga menunjukkan hasil bahwa jumlah siswa yang mencapai nilai KKM pada kelas eksperimen pada tes hasil belajar berjumlah 34 orang atau sekitar 94,4\%. Sedangkan pada kelas kontrol, jumlah siswa yang mencapai nilai KKM pada tes hasil belajar berjumlah 28 orang atau sekitar 78,7 \%. Hal ini menujukkan bahwa ada peningkatan hasil belajar setelah diberi perlakuan.

Besarnya peningkatan hasil belajar siswa pada kelas eksperimen dikarenakan pada proses belajar mengajar dengan menggunakan model pembelajaran kooperatif tipe STAD menuntut siswa untuk bekerja sama dalam proses pembelajaran. Dalam proses pembelajaran pada kelas eksperimen siswa dapat membuktikan dan menjawab permasalahan yang sering terjadi 
dalam kehidupan sehari-hari dengan cara bekerja sama dengan temannya. Selain itu meningkatnya hasil belajar siswa juga dikarenakan bantuan dari media animasi yang ditampilkan peneliti dan juga adanya penghargaan yang diberikan terhadap kelompok yang terbaik. Dari hasil data peningkatan postes antara kelas eksperimen dan kelas kontrol dapat dikatakan bahwa dalam hal ini ada perbedaan yang signifikan akibat pengaruh model pembelajaran ooperatif tipe STAD berbantuan media animasi terhadap hasil belajar siswa pada materi suhu dan kalor kelas X SMA Swasta Nusantara Lubuk Pakam T.P 2015/2016. Hal ini juga sesuai dengan uji hipotesis yang dilakukan oleh peneliti.

Dalam penerapannya, model pembelajaran kooperatif tipe STAD juga menuntut siswa untuk berfikir kritis, mampu menyelesaikan permasalah yang diajukan dengan cara bekerja sama, dan dapat meningkatkan hasil belajar kognitif siswa yaitu pada pengetahuan faktual. Selain itu model pembelajaran kooperatif tipe STAD dapat memberikan kesempatan pada siswa untuk memberikan pendapatnya saat bekerja sama dengan temannya dalam memecahkan masalah, sehingga siswa mampu untuk berpikir kritis, analitis, sistematis, dan logis dalam menemukan jawaban. Siswa dalam hal ini aktif dan antusias untuk bekerja sama dengan teman satu kelompok dalam menyelesaikan masalah yang telah diberikan oleh peneliti. Dan hal ini sangatlah berbeda dengan pembelajaran langsung yang hanya memberikan dan menjelaskan.
Tujuan kognitif model pembelajaran kooperatif tipe STAD dapat dilihat dari pengetahuan akademis faktualnya, dimana guru mengharuskan siswa untuk mengerjakan kuis-kuis tentang materi belajar. Soal-soal tes dalam kuis-kuis ini harus bertipe objektif, sehingga dapat segera diskor di kelas usai dikerjakan. Jika tujuan sosialnya, dapat dilihat dari kerja kelompok dan kerja sama timnya. (Arends, 2007 : 18)

Hal ini juga di dukung dengan hasil penelitian terdahulu yaitu: (1) Sigalingging, (2014) bahwa ada perbedaan hasil belajar siswa yang signifikan antara kelas yang menggunakan model pembelajaran kooperatif tipe STAD berbantu macromedia flash dan pembelajaran konvensional. (2) Brutu, (2013) bahwa ada perbedaan hasil belajar siswa yang signifikan antara kelas yang menggunakan model pembelajaran kooperatif tipe STAD dan pembelajaran langsung. (3) Sinaga dan Hakim, (2014) diperoleh ada perbedaan yang signifikan akibat pengaruh model pembelajaran kooperatif tipe stad terhadap hasil belajar siswa pada materi suhu dan pemuaian di kelas $\mathrm{X}$ semester II SMA Negeri 1 Delitua.

\section{KESIMPULAN}

Berdasarkan hasil penelitian yang diperoleh dari hasil analisis data dan pengujian hipotesis maka dapat disimpulkan ada perbedaan hasil belajar siswa akibat pengaruh model pembelajaran Kooperatif Tipe STAD Berbantuan Media Animasi terhadap hasil belajar siswa pada materi pokok Suhu dan Kalor di kelas X semester II SMA Swasta 
Nusantara Lubuk Pakam T.P 2015/2016.

\section{DAFTAR PUSTAKA}

Arends, R., I. (2007). Learning To Teach. Pustaka Pelajar. Yogyakarta

Arikunto. (2012). Dasar-dasar Evaluasi Pendidikan. Bumi Aksara. Jakarta

Brutu, S., U. (2013). Pengaruh Model Pembelajaran Kooperatif Tipe (STAD) Terhadap Hasil Belajar Siswa Pada Materi pokok Tekanan di Kelas VIII Semester GenapSMP Negeri 2 B.Purba T.P.2010/2011. Skripsi. Medan. FMIPA Unimed

Sigalingging, P., I. (2014). Pengaruh Model Pembelajaran Kooperatif Tipe Student Teams Achievement Divisions (STAD) Berbantu Macromedia Flash Terhadap Hasil Belajar Siswa Pada Materi pokok suhu dan kalor di Kelas X Semester II di SMA Negeri 1 Siantar Narumunda T.P.2013/2014. Skripsi. Medan. FMIPA Unimed
Sinaga, E., Y dan Hakim, ., A. (2014). Pengaruh Model Pembelajaran Kooperatif Tipe STAD Terhadap Hasil Belajar Siswa Pada Materi Suhu dan Pemuaian di Kelas X Semester II SMA Negeri 1 Delitua. Jurnal INPAFI (2) 4 PP 1-7

Slavin, R., E. (2005). Cooperative Learning. Nusa Media. Bandung

Sukmadinata.N.S,(2009), Metode Penelitian Pendidikan,PT Remaja Rosdakarya, Bandung

Tanjung, $\mathrm{R}$ dan Ramadhani, $\mathrm{H}$. (2013). Pengaruh Model Pembelajaran Kooperatif Tipe STAD Dengan Integrasi Karakter Terhadap Pembentukan Karakter dan Hasil Belajar Siswa Pada Materi Pokok Listrik Dinamis Di SMA Negeri 1 Stabat. Jurnal penelitian prosiding semirata FMIPA Universitas Lampung, Lampung , FMIPA UNILA 